\title{
The Effect of Environmental Performance and Environmental Cost on Financial Performance with Good Corporate Governance as the Moderating Variable
}

\author{
Miladiasari $^{1}$, Ratno Agriyanto ${ }^{2}$, Dessy Noor Farida ${ }^{3}$, Ari Kristin $\mathrm{P}^{4}$, Muhlis ${ }^{5}$ \\ Universitas Islam Negeri Walisongo Semarang ${ }^{1,2,3,4,5}$ \\ \{miladias218@gmail.com¹, ratnoagriyanto@walisongo.ac.id², dessy_nf@walisongo.ac.id , \\ ari_kristin@walisongo.ac.id ${ }^{4}$, muhlis@walisongo.ac.id ${ }^{5}$ \}
}

\begin{abstract}
This study aims to examine the influence of the environment and financial performance with good corporate governance as moderation. The independent variables are environmental performance and environmental costs. The measurement of environmental performance used PROPER. The measurement of environmental cost used a cost comparison between the costs of corporate social responsibility and net income. The dependent variable was financial performance as measured by Return on Assets. Good corporate governance was measured using the number of independent boards of commissioners. Quantitative research method was applied by employing WarpPLS application. The samples were manufacturing companies listed on the Indonesia Stock Exchange (BEI) 2017-2019. The results showed that environmental performance and environmental costs had no effect on financial performance. Good corporate governance did not moderate the effect of environmental performance on financial performance. Meanwhile, good corporate governance was able to moderate the effect of costs on the financial performance environment.
\end{abstract}

Keywords: Environmental Performance; Environmental Costs; Corporate Social Responsibility; Financial Performance

\section{Introduction}

Environmental problems are increasingly a concern for investors, consumers as well as the government. In Indonesia, there are many industrial conflicts such as natural damage due to excessive exploitation of nature that does not take environmental improvements into consideration [1]. Thus, companies are not only required to take the role in the treatment of waste, but also to meet the demands of society or consumers in the process of producing goods ranging from making raw materials to the disposal of product when consumed or used in order not to damage the environment [2].

The effort of the government to preserve the environment is by issuing regulations that is the Law of the Republic of Indonesia No. 32 of 2009 on Environmental Protection and 
Management, and Government Regulation of the Republic of Indonesia No. 101 of 2014 on Management of Hazardous and Toxic Waste. It shows that the government is very concerned about environmental management [3]. The government through the Ministry of Environment held PROPER (Program Penilaian Peringkat Kerja Perusahaan/Environmental Management Company Performance Rating Program) which is measured by the rankings of gold, green, blue, red, to black. This is done as a form of environmental responsibility.

Quoted from Sindonews.com, an example of a case of environmental pollution occurred in the activities of a Sinar Mas subsidiary. The government of Karawang Regency stopped the production activities of PT Sinar Mas's subsidiary, PT Pindo Deli Pulp \& Paper Mills 3 in Tamanmekar Village, Pangkalan District due to many complaints from the local residents because Pindo Deli 3 dumped liquid waste directly into the Cibeet River, which had previously been cracked down by the Task Force Citarum. However, rather than improving its waste management, the company continued to dispose waste with new sewage channels so that the government of Karawang Regency firmly stopped the company's production activities.

Environmental problems arise from interactions between environmental and economic activities. The high level of interaction gives a big impact on financial performance because the financial performance is the achievement of companies listed in the financial statements [4]. In addition, companies must ensure good corporate governance, which includes transparency in their social activities recorded in the company's financial statements.

Research relating to environmental performance, environmental costs with financial performance and good corporate governance include [5], [6], [7] which show that environmental performance has a positive effect on financial performance. However, this statement is not in line with research conducted by Vivianita et al [8] that there is no significant relationship between environmental performance and financial performance. Furthermore, research [9] states that environmental costs have a significant effect on financial performance.

From the description above, there is a mismatch of research results. Therefore, the researcher intends to review by adding one variable that is good corporate governance as a moderating variable and the researcher uses a sample of manufacturing companies in this study. Thus, the authors conducted research entitled "The Effect of Environmental Performance and Environmental Cost on Financial Performance with Good Corporate Governance as the Moderating Variable".

\section{Literature Review}

\subsection{Legitimacy Theory}

Legitimacy theory focuses on interactions between companies and society [10]. An organization tries to create a match between the social values inherent in its activities with the norms of behavior in the social system in which the organization is a part of this system [11] [12] [13]. The company wants to get legitimacy or recognition from the community that it has operated without violating the norms and rules in the community. There are social contracts that occur between the company and the community. For examples, corporate responsibility for waste recycling, factory waste management, organizing community training, and scholarships [14]. Therefore, the degree of application of legitimacy measures can help companies in overcoming problems encountered in a changing environment. Disclosure of annual reports is an attempt by companies to communicate their environmental activities and 
thus obtain legitimacy from the community in accordance with the principle of business continuity.

\subsection{Environmental Performance}

Environmental performance is the company's performance in creating a good environment. The company pays attention to the environment as a form of corporate responsibility and care for the environment. In Indonesia, one of the instruments that can be used in measuring environmental performance is PROPER (Company Performance Rating Assessment Program in Environmental Management). PROPER is a measuring tool used to determine the effect of environmental performance on the company's financial performance [15]. Business Performance Rating or activities submitted consist of: Gold, Green, Blue, Red and Black. In this study, environmental performance was measured using PROPER (Company Performance Rating assessment program) by giving scores as shown by Table 1 .

Table 1. PROPER Ranking Criteria

\begin{tabular}{crlc}
\hline No & Ratings & \multicolumn{1}{c}{ Information } & Score \\
\hline 1 & Gold & $\begin{array}{l}\text { Has consistently demonstrated environmental excellence in } \\
\text { the production process, implementing ethical and responsible } \\
\text { business towards the community. }\end{array}$ & 5 \\
2 & Green & $\begin{array}{l}\text { Has carried out environmental management more than what is } \\
\text { required in the regulations (beyond compliance) through the } \\
\text { implementation of environmental management systems and } \\
\text { utilize resources efficiently and implement good social responsibility. }\end{array}$ \\
3 & Blue & $\begin{array}{l}\text { Has conducted environmental management efforts required } \\
\text { in accordance with the provisions or applicable laws and regulations. }\end{array}$ & 3 \\
4 & Red & $\begin{array}{l}\text { Has made efforts to manage the environment but not in } \\
\text { accordance with the requirements as regulated in the legislation. }\end{array}$ & 2 \\
5 & Black & $\begin{array}{l}\text { Deliberately committing acts or omissions that result in pollution } \\
\text { or environmental damage, as well as violating applicable laws } \\
\text { and/or not implementing administrative sanctions. }\end{array}$ & 1 \\
\hline
\end{tabular}

\subsection{Environmental Costs}

Environmental costs are the internal and external costs associated with environmental damage and the protection measures undertaken by the company [16]. According to EPA [17], environmental costs must cover at least two main dimensions; first, costs that directly affect the net profit of a company (private costs), and secondly, costs to individuals, society, and the environment with the company is not responsible and cannot calculate these costs. These environmental costs can be seen in the allocation of funds for the Community Development Program listed in the company's financial statements or annual reports. This environmental cost is calculated by comparing the funds for the environmental development program with the net profit generated by the company [15].

\subsection{Financial Performance}

Financial Performance is an analysis conducted to see the extent to which a company has carried out using the rules of financial implementation properly and correctly, such as making a financial report that meets the standards and provisions in SAK (Standar Akuntansi Keuangan/Financial Accounting Standards) or GAAP (General Accepted Accounting 
Principle), and others [18]. In this study, the environmental performance was measured using a profitability ratio that was proxied by ROA (Return on Assets) [19]. in measuring financial performance because this ratio is important for management to evaluate the effectiveness and efficiency of company management in managing all company assets.

\subsection{Good Corporate Governance}

Good Corporate Governance (GCG) is a system that directs and controls a company with the aim of achieving continuity between the strength of authority required by the company to ensure its continued existence and accountability to shareholders. The main benefit for companies implementing GCG is to gain the trust of investors and the public. Companies that implement GCG are recognized as an increase in the credibility and performance of the company [20]. The implementation of GCG carried out by the company consistently from year to year can provide satisfactory results for shareholders and corporate stakeholders. Evaluation of the application of good corporate governance refers to the International Standards Code of corporate governance established by the OECD in connection with the requirements of the Indonesian Security Exchange Commission and Stock Exchange [21]. The characteristics of good corporate governance used in this study refer to research conducted by [8], which is proxied by the size of the independent board of commissioners.

\subsection{Hypotheses Formulation}

\section{a) The Effect of Environmental Performance on Financial Performance}

Environmental performancse is how the company's performance takes part in preserving the environment. Environmental performance is made in the form of ranking by an institution related to the environment. In this case, PROPER is an environmental rating program imposed by the Ministry of the Environment.

The greater the company's share in the environment, the better the company's image for investors and other external parties because good corporate treatment of the environment will be able to improve the company's financial performance. The results of this study are supported by research by [6] and [7] who prove that there is a positive influence between environmental performance on financial performance. However, there are also several studies which state that environmental performance does not have a positive influence on financial performance as shown by researches [5] and [8].

H1: There is a significant effect of environmental performance on the financial performance of manufacturing companies listed on the Indonesia Stock Exchange.

\section{b) The Effect of Environmental Costs on Financial Performance}

Environmental costs are costs incurred in the company's internal and external and all costs incurred related to damage and environmental protection. Meanwhile, according to [22], environmental costs are all costs associated with the creation, detection, remediation, and prevention of environmental degradation [9]. As such, environmental costs provide a framework for environmental responsibility and corporate financial performance. The results of this study are supported by the research of [9] which proves that there is a positive influence between environmental costs on financial performance. However, there are also 
several studies which state that environmental costs do not have a positive influence on financial performance, that is the research by [7]. Therefore, based on previous research and the elaborated arguments, a hypothesis can be proposed as follows:

H2: There is a significant effect of environmental costs on the financial performance of manufacturing companies listed on the Indonesia Stock Exchange.

\section{c) The Effect of Environmental Performance on Financial Performance with Good Corporate Governance as the Moderating Variable}

Good corporate governance is a mechanism used by the company to organize, control, supervise and manage the company and the company's internal stakeholders. One of these mechanisms is used to oversee the company's treatment with its environment, whether it is in accordance with its social contract with its stakeholders or not. Corporate governance in supervision becomes effective when the environmental performance disclosed by the company is carried out transparently and openly. On the contrary, corporate supervision becomes ineffective and weak when companies cover up their environmental performance just to gain recognition or legitimacy from their stakeholders [8]. The results of the study by [8] stated that the pros and cons of the disclosure of environmental performance is influenced by the strength of supervision and control of the corporate governance at the company. Therefore, based on previous research and the arguments, a hypothesis can be proposed as follows:

H3: There is a significant effect of good corporate governance moderating the effect of environmental performance on financial performance on manufacturing companies listed on the Indonesia Stock Exchange.

\section{d) The Effect of Environmental Costs on Financial Performance with Good Corporate Governance as the Moderating Variable}

Environmental costs that are held or budgeted by a company aims to support the company's activities. One of them is to support Good Corporate Governance. The implementation of Good Corporate Governance (GCG) is important to be applied consistently because GCG is expected to increase management supervision to encourage effective decision making, preventing opportunistic actions that are inconsistent with company interests. A good GCG is expected to increase public confidence in the company, especially investors and creditors because strong corporate governance will affect good perceptions for external parties compared to weak corporate GCG. Therefore the hypothesis proposed in this study is:

H4: There is a significant effect of good corporate governance moderating the effect of environmental costs on the financial performance of companies listed on the Indonesia Stock Exchange.

\section{Methods}

Type of research used in this study is quantitative research. The analysis used is WarpPLS 4.0 , that is the outer model, inner model, and hypothesis testing. The test is used to test the effect of independent variables (environmental performance and environmental costs) on the 
dependent variable (financial performance) and moderating variable (good corporate governance). The research data used secondary data that are the annual report of manufacturing companies on the Indonesia Stock Exchange (BEI) and the report on the results of the Performance Management Company Performance Rating Program (PROPER) of manufacturing companies that have been published.

The population in this study is manufacturing companies listed on the Indonesia Stock Exchange in 2017 to 2019. Meanwhile, the sample in this study is 15 companies taken using purposive sampling technique with the specified criteria including: (1) Manufacturing companies listing on the IDX during the period 2017 - 2019; (2) Manufacturing companies that consistently submit annual reports during the period 2017 - 2019; (3) Manufacturing companies that provide financial statements in rupiah; (4) Manufacturing companies that have a positive return on assets (ROA) value; (5) Companies that have had PROPER during the period 2017 - 2019.

\section{Results and Discussion}

\section{a) The Effect of Environmental Performance on Financial Performance}

Based on the results of data processing, the research results can be seen in Figure 1. The results of the first hypothesis proposed state that environmental performance has a significant effect on financial performance. Based on the results of the study, the significance value of the environmental performance variable of 0.32 is greater than 0.05 ; the environmental performance variable has no effect on financial performance. Based on the figure 1, the analysis of the effect of environmental performance shows a positive relationship on financial performance variables as seen by $\beta$ which is positive at 0.04 . Based on these results, $\mathrm{H} 1$ is rejected because environmental performance variables does not have a significant effect on financial performance variables.

\section{b) The Effect of Environmental Costs on Financial Performance}

The second hypothesis states that environmental cost variables significantly influence financial performance. Based on the results of the study, the $p$ value of the environmental cost variable of 0.06 is greater than 0.05 , so the environmental cost variable has no significant effect on financial performance. Based on the figure 1, the analysis of the effect of environmental performance shows a positive relationship on financial performance variables as seen by $\beta$ which is positive at 0.15 . Based on these results, $\mathrm{H} 2$ is rejected because environmental cost variables does not have a significant effect on financial performance variables.

\section{c) The Effect of Environmental Costs on Financial Performance with Good Corporate Governance as the Moderating Variable}

The third hypothesis states that environmental cost variables significantly influence financial performance that is moderated by good corporate governance. Based on the results of the study, the first $\mathrm{P}$ value of good corporate governance variable is 0.46 greater than 0.05 , so the good corporate governance as the moderating variable has no influence on environmental performance and financial performance. Based on the figure 1, the analysis of the influence of 
environmental performance has a positive relationship on financial performance variables shown by $\beta$ which is positive at 0.46 . Then it can be concluded that H3 is rejected, i.e. variable good corporate governance is not able to moderate between environmental performance variables with financial performance variables.

\section{d) The Effect of Environmental Costs on Financial Performance with Good Corporate Governance as the Moderating Variable}

The fourth hypothesis states that the environmental cost variable has a significant effect on financial performance that is moderated by good corporate governance. Corporate governance as a moderating variable has an influence between environmental cost variables and financial performance. Based on figure 1, the analysis of the effect of environmental costs has a positive relationship with the financial performance variable shown by $\beta$ which is positive at 0.28 . Then it can be concluded that H4 is accepted, i.e. variable good corporate governance is able to moderate between environmental cost variables with financial performance variables.

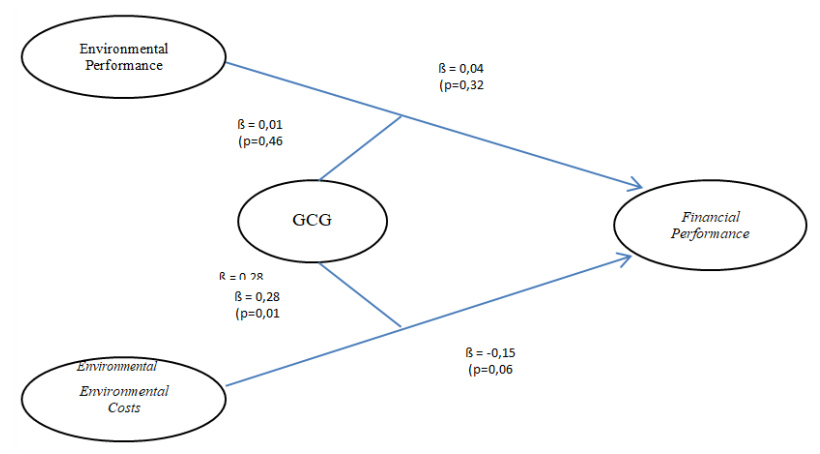

Fig. 1. Research Result

Environmental performance which can be considered sufficient can not necessarily guarantee good financial performance results. This indicates that stakeholders or the community feel that the results are not in line with expectations. They hope that the company can do more environmental management than required by law such as being able to utilize resources efficiently and implement 3R (Reuse, Reduce, Recycle). This study supports previous research conducted by [8] which states that environmental performance has no significant influence on financial performance.

The environmental costs that are expected to become long-term investments have not been proven in this study. It can be seen from the results of the study that there is no significant positive effect. It means that if environmental costs do not affect the company's financial performance. It can occur because the environmental costs incurred by the company are indicated to be additional expenses by the company. Revealed that sometimes companies ignore environmental costs incurred by companies, so that the results are not visible in the company's annual financial statements [23]. If the company continues to ignore, its impact on the financial statements will worsen due to the swelling environmental costs incurred. This study supports previous researches conducted by [5] and [6] which showed no significant influence between environmental cost variables and financial performance. 
Corporate governance in supervision becomes effective when the environmental performance disclosed by the company is carried out transparently and openly. Conversely, corporate supervision becomes ineffective and weak when companies cover up their environmental performance just to gain recognition or legitimacy from their stakeholders. This study also supports previous research, that is research conducted by [24] which states that good corporate governance is not able to moderate the influence of environmental performance and financial performance on economic performance.

The fourth hypothesis proposed states that the environmental cost variable has a significant effect on financial performance that is moderated by good corporate governance. Corporate governance as the moderating variable has an influence between environmental cost variables and financial performance. Based on figure 1, the analysis of the effect of environmental costs has a positive relationship with the financial performance variable shown by $\beta$ which is positive at 0.28 . Then it can be concluded that $\mathrm{H} 4$ is accepted, i.e. variable good corporate governance is able to moderate between environmental cost variables with financial performance variables. Implementation of Good Corporate Governance (GCG) is important to be applied consistently because GCG is expected to increase management supervision to encourage effective decision making, preventing opportunistic actions that are inconsistent with company interests. A good GCG is expected to increase public confidence in the company, especially investors and creditors. Because strong corporate governance will affect good perceptions for external parties compared to weak corporate GCG.

\section{Conclusion}

The proposed hypotheses are not proven that there is no effect of environmental performance on financial performance, there is no effect of environmental costs on financial performance, and there is no influence of good corporate governance as the moderating variable does not moderate the effect of environmental performance on financial performance. These results lead us to a conclusion that the company failed to legitimize environmental performance. Environmental performance has no impact on improving the company's financial performance. Environmental activities and costs do not generate internal and external motivation to boost financial performance. In other words, it can be concluded that environmental activities and costs are still symbols of not being institutionalized. However, there is a significant effect of good corporate governance as the moderating variable, that good corporate governance is able to moderate the effect of environmental costs on financial performance. These results illustrate that the commissioners have a role in increasing the benefits of environmental costs to improve financial performance. It is possible because the commissioners have a wider network to socialize to stakeholders.

\section{References}

[1] M. K. Rizki, R. Agriyanto, and Dessy Noor Farida, "The Effect of Sustainability Report and Profitability on Company Value: Evidence from Indonesian Sharia Shares," Econ. J. Ekon. Islam, vol. 10, no. 1, pp. 117-140, 2019.

[2] H. S. Homan, "Environmental Accounting Roles in Improving the Environmental Performance and Financial Performance of the Company," South East Asia J. Contemp. Business, Econ. Law, vol. 11, no. 1, pp. 9-15, 2016. 
[3] S. Julianah, "Analisis Faktor-Faktor Yang Berpengaruh Terhadap Kinerja Lingkungan," 2018.

[4] A. I. M. S. . Cna, L. M. Etale, and B. P. Frank, "The Impact of Environmental Cost on Corporate Performance: A Study of Oil Companies in Niger Delta States of Nigeria," J. Bus. Manag., vol. 2, no. 2, pp. 1-10, 2013.

[5] W. S. P. Tunggal and Fachrurrozie, "Pengaruh Environmental Performance, Environmental Cost dan CSR Disclosure terhadap Financial Performance," Account. Anal. J., vol. 3, no. 3, pp. 310-320, 2014.

[6] Haninun, Lindrianasari, and A. Denziana, "The effect of environmental performance and disclosure on financial performance," Int. J. Trade Glob. Mark., vol. Vol. 11, no. Nos 1/2, 2018, doi: 10.1504/IJTGM.2018.092471.

[7] R. R. Mustika, "Pengaruh environmental Performance, Environmental Cost terhadap Financial Performance dan CSR Disclosure," 2017.

[8] A. Vivianita and F. Nafasati, "Pengaruh Environmental Performance Terhadap Kinerja Keuangan Dengan Corporate Governance Sebagai Variabel Pemoderasi," J. REP (Riset Ekon. Pembangunan), vol. 3, no. 1, pp. 48-59, 2018, doi: 10.31002/rep.v3i1.792.

[9] L. M. Nababan and D. A. Hasyir, "PENGARUH ENVIRONMENTAL COST DAN ENVIRONMENTAL PERFORMANCE TERHADAP FINANCIAL PERFORMANCE (Studi Kasus pada Perusahaan Sektor Pertambangan Peserta PROPER Periode 2012 - 2016)," E-Jurnal Ekon. dan Bisnis Univ. Udayana, vol. 3, p. 259, 2019, doi: 10.24843/eeb.2019.v08.i03.p03.

[10] C. Deegan, "Introduction: The legitimising effect of social and environmental disclosures - a theoretical foundation," Accounting, Audit. Account. J., vol. 15, no. 3, pp. 282-311, 2002, doi: 10.1108/09513570210435852.

[11] E. Smullen, J. Finnan, D. Dowling, and P. Mulcahy, "Bioconversion of switchgrass: Identification of a leading pretreatment option based on yield, cost and environmental impact," Renew. Energy, vol. 111, pp. 638-645, 2017, doi: 10.1016/j.renene.2017.04.059.

[12] N. F. Awwaliyah, R. Agriyanto, and D. N. Farida, "The effect of regional original income and balance funding on regional government financial performance," J. Islam. Account. Financ. Res., vol. 1, no. 1, 2019.

[13] R. Agriyanto, "Redefining Objective of Islamic Banking; Stakeholders Perspective in Indonesia," Econ. J. Ekon. Islam, vol. 6, no. 2, pp. 77-90, 2015.

[14] I. Irfansyah, H. N. L. Ermaya, and K. Septyan, "the Influence of Environmental Performance, Environmental Disclosure and Environmental Cost on Economic Performance," Econ. Account. J., vol. 1, no. 2, p. 87, 2018, doi: 10.32493/eaj.v1i2.y2018.p87-94.

[15] I. Camilia, "Pengaruh Kinerja Lingkungan dan Biaya Lingkungan Terhadap Kinerja Keuangan Perusahaan Manufaktur," 2016.

[16] D. . Kieso, J. . Weygandt, and T. . Warfield, Akuntansi Intermediate, Terj., Jilid I. Jakarta: Erlangga, 2007.

[17] USEPA, "U.S. Environmental Protection Agency. Environmental Accounting Case Studies: Green Accounting at AT\&T.," EPA\# 742-R-95. 1995.

[18] I. Fahmi, Analisis Laporan Keuangan. Bandung: Alfabeta, 2017.

[19] W. S. P. Tunggal and F. Fachrurrozie, "Pengaruh Environmental Performance, Environmental Cost Dan Csr Disclosure Terhadap Financial Performance," Account. Anal. J., vol. 3, no. 3, 2014, doi: 10.15294/aaj.v3i3.4200.

[20] D. Prasinta, "Pengaruh good corporate governance terhadap kinerja keuangan," 
Account. Anal. J., vol. 1, no. 2, 2012.

[21] M. Adam, Mukhtaruddin, N. Soraya, and H. Yusrianti, "Good Corporate Governance and Cost of Debt: Listed Companies on Indonesian Institute for Corporate Governance," Asian Soc. Sci., vol. Vol. 11, no. No. 25, pp. 58-77, 2015, doi: 10.5539/ass.v11n25p58.

[22] D. R. dan M. M. M. Hansen, Cost Management Accounting and Control. 2007.

[23] V. Magness, "Strategic posture, financial performance and environmental disclosure," Accounting, Audit. Account. J., 2006.

[24] M. I. Rahmawati and A. Subardjo, "Pengaruh Pengungkapan Lingkungan Dan Kinerja Lingkungan Terhadap Kinerja Ekonomi Yang Dimoderasi Good Corporate Governance," Bul. Stud. Ekon., vol. 22, no. 2, pp. 200-226, 2017. 